\title{
Public Opinion, Journalism and the Question of Finland's Membership of NATO
}

\author{
JUHO RAHKONEN
}

\begin{abstract}
The big question behind the research on media and democracy is: do media influence public opinion and the actual policy? The discussion about Finland's NATO membership is a case in point. Since the collapse of the Soviet Union and the end of the Cold War, there has been a continuous public debate about whether Finland should join NATO. In the last 16 years, however, public opinion on NATO membership has not changed much. Despite the changes in world politics, such as NATO enlargement and new weapons technology, Finns still rely on military non-alliance and want to keep their own army strong. During the last ten years, there seems to be no correlation between media coverage and public opinion: pro-NATO media content has not been able to make Finns' attitudes towards NATO more positive. The information provided by most of the Finnish newspapers is different from the way ordinary people see NATO. In the papers' view, joining the alliance would be a natural step in Finland's integration into Western democratic organizations. Ordinary people on the contrary consider NATO more as a (U.S. led) military alliance which is not something Finland should be a part of. Historical experiences also discourage military alignment. In the light of data drawn from newspaper articles and opinion polls, the article suggests that journalism has had only a slight effect on public opinion about Finland's NATO membership. The NATO issue does not count for much in any measurements that have been made regarding the preferences of Finnish voters. As the NATO issue is not considered to be important, most people do not have enough motivation to learn about NATO. Thus, the journalistic interpretation of NATO has not reached the general public, leaving the impact of the media limited.
\end{abstract}

Key Words: journalism, public opinion, media influence, NATO, Finland

\section{Introduction}

During the Cold War there was virtually no room for a public discussion about Finland's NATO membership. Finland and the Soviet Union had the YYA treaty (Agreement on Friendship, Cooperation and Mutual Assistance), concluded in 1948, and the Soviets sought to deter Western forces from attacking Russia through Finnish territory. The YYA treaty also recognized Finland's desire for a policy of neutrality, which meant remaining outside major power conflicts. 
Since the early 1990's - after the collapse of the Soviet Union and the abandoning of the YYA treaty - there has been a lively public debate about whether Finland should join NATO. Despite pro-NATO voices heard among the political and media elite, the opinion polls have without exception indicated that the majority of Finns want Finland to remain a militarily non-aligned country. Support for NATO membership has varied from 16 to 34 per cent, while the opposition has remained as high as 58 to 79 per cent. (MTS 2006.)

This article examines the controversial relationship between media content and public opinion. The media coverage of issues related to NATO has mostly been favourable, but why have Finns' opinions not become more positive about NATO membership? Shedding light on this question is the main goal of my article. Another purpose of the article is to explain the relationship of public opinion, media and foreign policy in the Finnish context.

\section{Public Opinion, A Historical Perspective}

Public opinion indisputably plays a crucial role in the question of Finland's membership of NATO. For example, three biggest political parties in the country have taken the line that, before possibly making a decision on NATO membership, Finland should have a referendum or at least wide public support for the application. Now that this public support does not exist, Finland's NATO membership is not on the agenda of the political parties at least in the next few years.

Public opinion can be understood widely (Splichal 1999): the result of a democratic election is an expression of public opinion as is the outcome of opinion polls. In this article, however, I use the term in a narrower sense: when I write "public opinion", I mean the outcome of an opinion survey or surveys. I do this for two reasons: First, too broad an understanding of concepts weakens their explanatory power. Second, there is a fundamental difference between the parliamentary election system and direct democracy, such as polls and referendums. In the former, people have an opportunity to express their opinion only when the elections are held. In the latter, people's voices also become public between the elections. Moreover, when people vote, they express their opinion of the candidates, but they cannot express their opinions on all political issues to come. Thus, more direct forms of democracy are necessary alongside the parliamentary system. However, the most important feature in public opinion is that all opinions are equal. Both in elections and opinion polls, everybody has one universal vote and everybody is as likely as anybody else to be selected for the random sample of an opinion poll (Suhonen 1997, 234).

The role of public opinion varies in different societies. In Finland there is a strong tradition of Hegelian thought, which has dominated Finnish national philosophy since the $19^{\text {th }}$ century. Finland's national philosopher, J.V. Snellman, also an acclaimed statesman, author and journalist, was a student of the German philosopher G.W.F. Hegel. Snellman introduced Hegelian thought in Finland and had a fundamental impact on the development of the Finnish nation state. In his works on public opinion Snellman emphasized its collectivist character. According to Snellman $(1846 / 2005,92)$, an individual may have to act more or less against his or her values and opinions, but a large body of citizens always reaches what it feels to be right and beneficial, and therefore public opinion cannot go wrong. In Snellman's times there were no modern polling techniques, but the principle was same. Snellman believed that the wisdom of many is better than individual thinking. 
However, Hegel and Snellman's thoughts may have also weakened the role of public opinion in Finland. According to Hegelian philosophy, the state is the consummation of man as finite. Hegel's notion of "objective spirit", a presupposed system of culture, leads us to consider the state (and society) as subject. Society is not merely a sum of individuals, but it is the fulfilment of man's development. Due to the impact of Hegelianism, there has never been much room in Finnish political thought for the liberalist idea of separate, privately thinking individuals. Compared to other developed Western countries, Finland is relatively collectivistic (Hofstede 2001).

Indeed, public opinion in Finland has been given a less significant role than in many other Western democracies, especially Anglo-Saxon countries (Forsberg et. al. 2001, 129). Although their actual impact on policy may be considerable, the significance of opinion polls is often underestimated. The political and other elite in Finland tend to emphasize the parliamentary election system at the expense of more direct forms of democracy, such as opinion polling and referendums. In fact, there have been only two referendums during the period of Finnish independence, which began in 1917. The first, in 1931, was about ending the prohibition on alcoholic beverages, and the second, in 1994, about joining the European Union. Meanwhile, neighbouring Sweden has held six referenda, the most recent of them about joining European Monetary Union.

The strong tradition of political realism leads many Finnish elite members to exclude public opinion from foreign policy issues. Although internal issues should be decided in accordance with the will of the majority, this is not the case in foreign policy issues, which are too remote and complex for ordinary citizens. According to political realism, popular foreign policy is not always good foreign policy (Forsberg et al. 2001, 130). Political realism has its roots in World War II and the Cold War. "We can do nothing about geography", said President Juho Kusti Paasikivi, in office 1946-1956. By this he meant Finland's position between East and West and the delicate balance with the neighbouring Soviet Union. Finland remained outside the Cold War blocks, but in foreign policy the Soviet Union had a considerable effect. Despite this, Finland had an opportunity to develop into a western market economy. Thus, it can be said that Finland was a winner in the Cold War (Visuri 2006, 318).

However, opinion polls have served in the making of Finnish foreign policy for decades. Sometimes their publicity has been more visible than usual. Occasionally they have even seemed to be part of the political system. At the end of 1978 and the beginning of 1979 there was an exceptionally lively and intense public debate on Finnish foreign policy and public opinion on it. The debate started from an opinion survey, commissioned by the quality daily Helsingin Sanomat and conducted by Suomen Gallup Oy, the Finnish Gallup Ltd., (this poll is later referred to as HS-Gallup, the name used by the newspaper itself). On 12 December 1978 Helsingin Sanomat ran a big news article on Finns' foreign policy attitudes. The headline showed strikingly the most newsworthy part of the survey: "Our Foreign Policy Faces Increased Criticism for Shifting towards the East".

Slightly more than half of Finns estimate that our neutrality-seeking foreign policy has been carried out well. However, about one third assert that Finland's foreign policy has shifted too much towards the East. Appreciation for Finland's foreign policy has considerably decreased and criticism of a shift to the East significantly increased during the last six years, indicates a survey by Suomen Gallup Oy. 
Given Finland's delicate position between Western capitalist democracies and the Eastern communist world, all "shifts" to one side or the other would appear dramatic. During the Cold War, the official foreign policy of Finland was neutrality - a fact that was also emphasized in the poll discussed here. In such a political situation, publishing the HS-Gallup was like waving a red rag at a bull. Nevertheless, it emphasized the importance of public opinion in formulating the country's foreign policy.

\section{Opinion Polls in Finland Today}

Since the late 1970's, the attitude of Helsingin Sanomat towards public opinion has become more sceptical. In 1978 HS stated that opinion polls help to fulfil the mission of democracy, but in 2005 the newspaper gave polls and public opinion much less weight. The shift can be seen in the following quotations, both from leading articles (the italics are mine).

Although the practising of neutrality policy has not basically changed, the increased criticism of it among our own country's citizens cannot be ignored. It [public opinion] is reality, which may also affect the image of Finland abroad. In this sense, too, it is a challenge to which the people making foreign policy should be able to respond. (17 December 1978)

Everything is fine as long as the citizens' opinions match with the views of foreign policy leaders. However, the opinion of the majority of the people cannot be a guideline for foreign policy wisdom. (*) The government has to trust its own wisdom, but in big issues it should be able to turn the citizens to its side. (10 November 2005)

While in 1978 HS considered public opinion as a guiding force, 27 years later the paper thought that it is merely a force that needs to be guided. This view is nowadays widely shared within the Finnish media elite. For example, Risto Uimonen, editor-inchief of the newspaper Kaleva, wrote in his column of 23rd October 2005 that political leaders should not "hide behind people's backs". "The leaders ought to lead, that's why they have been elected to their high positions". This comment could be cited from any of the columns written by the editors of Finland's biggest newspapers and magazines. Their message has been unanimous: Successful foreign policy requires strong leadership, but in big questions the leaders should be able to shape public opinion. Among the Finnish media elite there is strong support for a top-down model of democracy, and little sympathy for the bottom-up model.

It is somehow controversial that while neo-liberal thinkers appreciate concepts based on active individuals, such as "civil society" and "civic participation", they ignore the wisdom coming from public opinion. Obviously this is because in Finland the opinions of the elite are nowadays quite different from those of the ordinary citizens. During the Cold War the economic and media elite got support from public opinion: both wanted to keep a distance from the Soviet Union and make Finland a more Western, liberal market economy. Now that this goal has been achieved, public opinion has become rather a problem for the elite: people do not want to join NATO, they have critical attitudes towards the United States and its foreign policy, and they want to preserve the welfare state despite the high taxation it requires (Torvi \& Kiljunen 2005). 
According to Thomas Risse-Kappen (1991, 480), the differences in political institutions, policy networks, and societal structures play a crucial role in how public opinion affects foreign policy. Therefore it is important to highlight the most characteristic features of Finland. The principles of universal welfare state and a tri-partite decisionmaking process, where state, employers and employees sit at the same table, enjoy widespread support within Finnish society, although they have recently been criticized as oldfashioned in the era of globalization. The basic structures of the welfare state survived even under the austere conditions of the economic depression in the early 1990's, although many benefits were reduced.

The consensus-seeking nature of Finnish society has its historical roots in the aftermath of World War II: having barely maintained her independence, Finland could not afford any internal conflicts which would have weakened the country's position. In order to ensure peace within society, political forces from both left and right were integrated into one and the same mission - reconstruction of the country after war. Consensus was also desirable because there had been a disastrous civil war in 1918 which had divided Finns into two blocks, the left-wing Reds and the right-wing Whites. After World War II, every citizen was needed to get Finland back on her feet.

In international comparison, Finland is still a relatively state-central and corporatist society. In many big issues the Finnish elite is consensus-seeking, and the acceptance of basic political choices is widely shared. This could be seen clearly in 1994, when there was a public debate about whether Finland should join the European Union. The elite were nearly unanimous in supporting membership, and only a few organizations, such as the Central Union of Agricultural Producers and Forest Owners, resisted. The consensus was also obvious in the media. Journalists interviewed after the decision felt that it was difficult to write critically about the EU, because the elite were so unanimous (Mörä 1999, 239). However, public opinion was divided: in the 1994 referendum only 57 per cent of the voters supported Finland's EU membership. In the question of Finland's NATO membership, the elite have not been as unanimous as in the EU issue. Quite the contrary: many of the leading politicians, such as the President and the Minister of Foreign Affairs, take a sceptical view of NATO and do not support Finland's membership. (Rahkonen 2006.)

The opinion polling in Finnish foreign policy can be described as in Figure 1. It is a kind of tri-partite system. This highlights the consensus-seeking nature of Finnish society.

Figure 1. The Triangle of Power within Finnish Opinion Polling

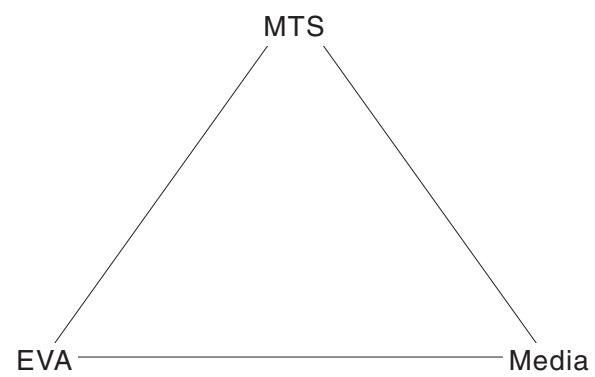

MTS, The Advisory Board for Defence Information, is a permanent parliamentary committee administrated by the Ministry of Defence. MTS observes the changes in Finnish 
public opinion by annually commissioning at least one survey, regarding matters such as NATO membership, the mandate for military interventions, and the resources of the Finnish Defence Forces.

Since 1964, MTS has annually asked Finns' opinion about how well Finland's foreign policy has been handled. The share of those who think foreign policy has been handled well has varied from 62 per cent in 1991 to 96 per cent in 1971 (MTS 2006, 46). Without exception, a vast majority of Finns has been satisfied with their country's foreign policy. However, the state does not commission polls, at least not first and foremost, in order to make its foreign policy suit citizens' preferences, but rather seeks to keep them under control and prevent the emergence of undesirable opinions. (Suhonen 1997, 228.)

When talking about Finns' opinions of foreign policy, one cannot ignore the name of EVA, the Finnish Business and Policy Forum. EVA is a pro-market think-tank financed by the Finnish business community. It encourages public discussion by publishing reports and organizing debates. EVA's Board of Directors gathers together 25 business leaders from the top of Finnish economic life.

EVA's policy proposals are mainly right-wing, including initiatives for tax cuts and market deregulation. In foreign policy issues, EVA supports more intense cooperation with the United States and all Western organizations, such as NATO. However, the results of EVA's opinion surveys are often in sharp contrast with its own policy. The ordinary people prefer nonalignment and keeping taxes at their present level in order to preserve the structures of the welfare state, while EVA campaigns for the privatization of now public services. People appreciate secure jobs more than dynamic competition. (Torvi \& Kiljunen 2005).

The media play an important part not only as publishers of polls but as pollsters themselves. Opinion polling started in Finland soon after World War II. In autumn 1945, the first polling company, Suomen Gallup Oy, was established. From the beginning, the mass media - especially Finland's largest newspaper Helsingin Sanomat - played a prominent role in making the polls part of the everyday public sphere. Helsingin Sanomat has a powerful position in the Finnish media field. With a circulation of more than 400,000 , it is able to make itself heard and quoted by other media. Therefore its opinion polls often command major attention.

Helsingin Sanomat has been independent since 1932, as the paper abandoned its connections to liberal-bourgeois Progressive party. However, echoes of progressive thinking still resound on the pages of HS. Nowadays, Helsingin Sanomat can be described more than anything as a liberal quality daily. It supports Finland's integration into Western institutions, such as the European Union and NATO. Only recently, in October 2006, the paper made its NATO support official and visible to everybody, as the editor-in-chief Janne Virkkunen wrote in his column that Finland should join the alliance.

The overall message of the Helsingin Sanomat NATO articles has long been that Finland should join the alliance (Rahkonen 2006). The fundamental argument of HS is ideological: Finland is a western, liberal democracy, and part of the European tradition, which according to HS is based on the Enlightenment. Therefore Finland should belong to every organization that represents those values. However, HS does not fully support present U.S. foreign policy and Republican ideology, because it violates some of the main principles of the liberal tradition, such as keeping state and religion separate. When it comes to U.S. politics, Democrats are certainly preferable to HS over Republicans. 


\section{Why don't People Change Their Mind about NATO?}

In some cases, a relationship can be found between media content and public opinion: During major world crises, such as the war in Kosovo in 1999, in Afghanistan in 2001, and in Iraq in 2003, the support for NATO membership among Finns has been lower than in more peaceful times (MTS 2006). These crises attract huge attention in the mass media. NATO did participate in the Kosovo and Afghanistan operations, but NATO as an organization was not involved in the U.S. invasion of Iraq. In point of fact, two powerful NATO countries, France and Germany, opposed the war. Despite this, the Iraq War was followed by a considerable decline in Finns' support for NATO membership.

However, when one looks at a longer period, no correlation can be found. Figure 2 shows the number of NATO articles in Finland's four largest newspapers monthly from the beginning of 2003 to the middle of 2004. The columns in the figure show the support for NATO membership at that time. The coverage of NATO varied dramatically from month to month, but public opinion changed only slightly. The data was gathered from several opinion polls commissioned by different media and institutions. From January to February 2003 there was a decline in support for NATO membership, but this was not a result of NATO journalism but rather the U.S. invasion of Iraq.

In my dissertation (Rahkonen 2006) I explored how NATO is covered in the Finnish media. I discovered that in the pages of newspapers NATO appears to be rather a political than a military alliance. Only in 146 out of 1362 articles (11 per cent) the NATO question was directly connected to military forces, whereas in most of the articles it was presented as a political issue. The analysis of the illustration shows a similar trend: 66 per cent of all the images represented people, usually politicians, with their clean suits. Only in 21 per cent of the images were there soldiers, tanks, strategic maps or other military things. The result: in journalism NATO is represented as a political rather than as a military organization. This differs from the way ordinary people see the alliance. Obviously the difference of the views is caused by the fact that journalists, especially editors, identify themselves with a socio-economic reference group which is different from that of the ordinary people. To put it simply, the journalistic interpretation of NATO is elitist. Opinion surveys have shown that the higher the income and social status, the more likely a person is to support Finland's NATO membership (MTS 2006). However, it seems that in television NATO is more often represented as a military alliance than in print media, but I do not have comparable data on this.

All the four newspapers in Figure 2 are in favour of Finland's NATO membership: the powers and expectations of the journalistic profession tend to make NATO membership look like a probable future scenario. Journalists question the decision-makers' assurances that Finland's policy of non-alliance will continue. The procedures that make journalism support Finland's NATO membership are discussed closer below, in Table 1.

The combined circulation of Finland's four biggest newspapers, 908500 copies, is about 40 per cent of the total circulation of Finnish dailies (Statistics Finland 2004, 520). What about the rest of the media? At that time NATO was also in the headlines of other newspapers, not to mention television and radio. There is no systematic data available on this, but qualitative interpretation indicates that most of the other media were also in favour of NATO membership.

At the end of November 2003 I took the editorials of 36 major newspapers and weekly magazines for closer examination. It appeared that 19 of them clearly supported Finland's military alignment, whereas 12 did not express their opinion unambiguously. Only five newspapers stated in their editorials that they did not want Finland to ally 
Figure 2. Coverage of NATO Issues in Finland's Four Biggest Newspapers and the Support for NATO Membership from January 2003 to June 2004

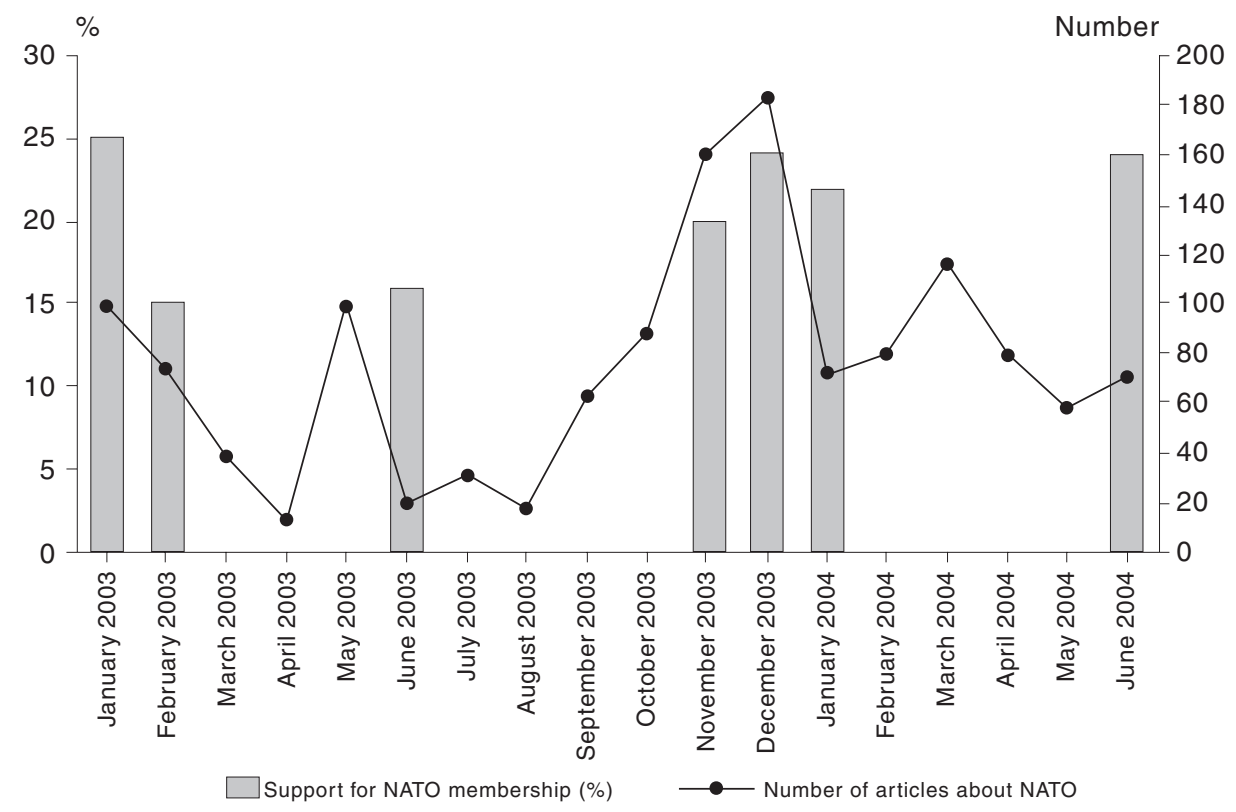

herself with NATO. These were the Communist Party's Tiedonantaja (The Informant), the Green Party's Vihreä Lanka (The Green Thread) and three papers - Suomenmaa, Ilkka, and Keskisuomalainen - which are close to the agrarian Centre Party. I have not analysed electronic media systematically, and my knowledge of it is based on qualitative interpretation. It is difficult to make a watertight analysis of the overall media coverage of the NATO question, but it is without doubt that those media that are against Finland's NATO membership represent a minority in the Finnish public sphere.

At the end of 2003 there was exceptionally intense coverage of NATO, more than 180 articles per month, in these four newspapers alone (see Figure 2). It could be supposed that this amount of media content would bring the NATO issue to the fore and therefore make NATO more familiar to Finns. It could have had an impact on people's minds, increasing support for NATO membership. But this did not happen: a poll conducted in June 2004 indicated that the share of citizens who would like Finland to join NATO had not changed. This is even more surprising considering that in March 2004 seven new members joined NATO, including Estonia, which has always had a close relationship with Finland.

There is no comparable data on the amount of NATO journalism after June 2004, but it seems that in 2006 the coverage of the NATO question decreased. During the presidential election campaign of late 2005 and early 2006, there was some debate about whether Finland should join NATO, but the intensity was far from that of the heyday of NATO journalism, which was at the end of 2003.

According to an opinion survey commissioned by HS in early 2004, the main reason for Finns to remain militarily non-aligned is that they do not want Finland to be involved in remote crises. Earlier surveys also indicate that Finns - like many other European nations - consider NATO as a U.S.-dominated alliance. Since the invasion of Iraq, Finns have become more critical of the United States' role in world politics. This opinion also 
has historical dimensions: as mentioned in the beginning of the article, from 1948 to 1991 Finland and the Soviet Union had the YYA treaty (Agreement on Friendship, Cooperation and Mutual Assistance). The YYA treaty recognized Finland's desire to remain outside great-power conflicts. This desire persists in the Finnish cultural memory, and therefore NATO does not look like a good thing in Finns' eyes.

Although Finland aims to remain militarily non-aligned, her cooperation with NATO is close and intensive. The majority of Finns, 56 per cent, accepts Finland's participation in NATO-led crisis management operations, and 67 per cent even support Finland's position in Partnership for Peace, NATO's program for non-members (MTS 2006) as of 1994. However, this cooperation does not mean the same thing as membership, since NATO countries belong to collective defence, the fifth article. Journalists often miss this difference, thereby creating a future scenario in which NATO membership seems inevitable. The following extract is a typical example of this kind of journalism:

Finland is stealthily edging closer to NATO membership. The cooperation with NATO is so close that Finland's non-alignment can be questioned, journalist Pekka Ervasti and member of parliament Jaakko Laakso write in their book published on Wednesday. (...)

In the authors' opinion, every action has been taken in order to advance Finland's compatibility with NATO. Ervasti and Laakso consider that Finland has been sidled up to [NATO] by throwing dust in the eyes of the public. The steps towards more intensive cooperation have been diminished.

Finland is far deeper inside NATO's activities and structures than usually is known”, Ervasti says. (...) (STT/Kaleva, 5 June 2002)

Despite its sensationalist tone, the news article cited above was not published in a yellow paper, but in a major quality daily. The article was originally from STT, the Finnish News Agency. At the time it was published, in 2002, the political situation in the world looked more favourable for Finland's NATO membership than today - in 2002 some experts interviewed in the media even predicted that Finland's NATO membership would be a reality within a couple of years. The U.S invasion to Iraq marked a watershed in Finnish NATO discussion; since 2003 membership has looked less probable than before.

Although the Finnish media coverage has been mostly favourable towards NATO membership, it has also been controversial. Some procedures in the media support military alignment, while others support military non-alignment. Table 1 presents a summary of the findings of my dissertation (Rahkonen 2006). There are two kinds of procedures in the media: those that push Finland towards NATO membership (at left) and those that have an opposite tendency (at right).

The left column in Table 1 weighs more in self-understanding of the media elite, but in ordinary people's minds the right column certainly carries more weight. The left column is more dependent on the practices and routines of journalistic work; the right column is more dependent on the external reality, which journalism can do little, if anything, about. Of course, it is journalism that reports these issues and brings them to our notice, but it does not shape their overall message. In summary it can be said that Finnish journalism tends to make NATO more favourable than it would otherwise be, without the intervention by journalist practices and routines. In other words, journalism is more favourable to NATO membership than its audience.

The powers and expectations of the journalistic profession tend to make NATO membership look like a probable future scenario. This may be due in part of the ten- 
Table 1. How the Media Support and Resist Finland's Membership of NATO

Support NATO membership (Practices and routines of the journalistic work)

Journalism brings the NATO issue to the fore. As a result, NATO is gradually becoming a familiar topic and part of the everyday conversation.

Journalists question the decision-makers' assurances that Finland's policy of nonalignment will continue. Therefore, the notion that she will join NATO in any case is promoted.

In leading articles and columns, politicians are urged to make quick decisions about NATO.
Resist NATO membership (The external reality which journalists can do little about)

There is extensive coverage of world crises (including Kosovo and Iraq) and as a result negative associations with Nato have emerged.

The continuing message from the decisionmakers is that Finland is not going to join NATO, at least in the near future.

Opinion polls repeatedly show that the majority of citizens are against military alignment.

dency in the media to push politicians to make straightforward and unambiguous statements. According to the opinion polls, the majority of Finns want Finland to remain a militarily non-aligned country, while the majority also estimates that Finland is on the way to joining NATO (MTS 2006). It is possible that the media's tendency to reach out to the future and question the prevailing policy (military non-alignment) has affected public opinion about Finland joining NATO. This may be the most significant effect journalism has had on Finns' opinions on NATO issue. The fact that the security policy debate necessarily lacks openness encourages various conspiracy theories.

Because public opinion appears to be stable, it should be somehow structured. In point of fact, research has shown that citizens' foreign policy opinions in different countries are structured by underlying ideological and other dimensions (Bjereld \& Ekegren 1999). To see what is behind people's NATO opinions, I took one of the polls shown in Figure 2 for closer examination. This is the poll commissioned by MTS (The Advisory Board for Defence Information) and conducted by Taloustutkimus Oy (Economy Research Ltd.) in December 2003.

A factor analysis shows that supporting the current defence system has little to do with people's opinion about NATO membership: these two things are loaded on different factors. Obviously in Finland there is such wide support for general conscription that most people want to retain it regardless of their NATO opinion (this is also the case in the media: majority supports general conscription). However, international orientation has quite a lot of explanatory power in Finns' opinions on NATO membership. If a person would like to see the EU with its own army, the EU with closer co-operation with NATO, and Finland participating in international operations without a UN mandate, he or she is likely to support Finland's military alignment, which in practice means joining NATO. (Rahkonen 2006.)

The internationally oriented people are more likely to support NATO membership. Therefore, if the security political content of a newspaper is internationally oriented, it can be assumed that the paper will promote Finland's NATO membership. The largest newspapers belong to this category. However, there are some regional newspapers whose orientation is national. Their journalistic content can be seen as rather supporting the status quo than promoting NATO membership. (Rahkonen 2006.) But, as men- 
tioned above, NATO-sceptical papers constitute a small minority in the Finnish media field.

\section{Conclusion}

Many observers, both domestic and foreign, have wondered why on earth Finland has not joined NATO among 21 of the 27 EU countries. This article suggests that it is not because of the media but despite the media. Journalists, especially those of the biggest newspapers, have for many years tried to highlight the "true" nature of NATO: it is not merely the Cold War military block it used to be, but rather a modern crisis management organization and a natural part of Finland's integration into the West. However, the public is not convinced.

The biggest newspapers, published in the metropolitan area, are urban and westernoriented. Their overall message is that Finland should be a member of every western democratic organization, including NATO. Some regional newspapers are traditionally and nationally oriented and have a conservative, patriotic profile. Their overall message is that Finland should rely on its own defence system and remain militarily non-aligned.

The findings of this article indicate that the way journalism handles NATO has only a limited effect on Finnish public opinion; other factors, most notably historical considerations, seem to sway public opinion more. However, this conclusion needs to be clarified, because it seems to be in contrast with earlier research. For example de Vreese (2004) found that the journalistic framing of issues does have a considerable effect on the way people interpret them. But why in the case of NATO question have people not adopted the journalists' interpretation of NATO? (Ordinary people consider NATO to be a U.S. led military alliance, whereas in journalism it is shown as merely a modern crisis management organization.)

Perhaps part of the answer is here: election for leadership in Finland is only remotely related to the NATO issue which does not count for much in any measurements that have been made regarding the preferences of Finnish voters. For example, social security, care of the elderly and wages are far more important issues for voters than the question of NATO membership. As the NATO issue is not considered to be important, most people do not have the motivation to read, listen or watch journalism about NATO. Thus, the journalistic interpretation of NATO has not reached the general public, leaving the impact of the media limited.

\section{Notes}

1. I am grateful for the comments of Professor James S. Fishkin, Stanford University, when he visited Tampere in September 2006. Professors Pertti Suhonen, Kaarle Nordenstreng and Heikki Luostarinen, University of Tampere, as well as an anonymous referee, gave me invaluable feedback on earlier versions of this article. Virginia Mattila of the University of Tampere helped me with my English.

2. Figure 2 is based on two kinds of material: 1) newspaper coverage of NATO issues and 2) opinion polls on Finland's NATO membership. The newspaper material consists of 1362 articles published in the four biggest newspapers in Finland, Helsingin Sanomat (circulation 440 000), Ilta-Sanomat (204 000), Aamulehti (136 000) and Iltalehti (126 000). Their combined circulation covers about 39 per cent of the total weekday circulation of the Finnish dailies (Statistics Finland 2004, 520). Smaller newspapers rely heavily on news agencies in reporting news on national and international level, and hence their news on NATO often follows the general agenda. Due to the national and international scale of the issue, it may be assumed that this material is enough to ensure a reliable overview of Finnish NATO journalism in the period. The research period is $1^{\text {st }}$ January 2003 to $30^{\text {th }}$ June 2004, and 
all articles about NATO were included. From the same period I also gathered the results of published opinion polls on Finns' NATO attitudes. There were seven: January 2003 (commissioned by Helsingin Sanomat), February 2003 (Finnish News Agency, STT), June 2003 (STT), November 2003 (Finnish Business and Policy Forum, EVA), December 2003 (Advisory Board for Defence Information, MTS), January 2004 (Finnish Broadcasting Company, YLE), and June 2004 (Ilta-Sanomat). The polls were conducted by Finnish Gallup Ltd. (Suomen Gallup Oy) or Market Research Ltd. (Taloustutkimus Oy). The results of the polls are shown in Figure 2 alongside the newspaper coverage of NATO.

\section{References}

Bjereld, Ulf \& Ekengren, Ann-Marie (1999) Foreign Policy Dimensions: A Comparison between the United States and Sweden, International Studies Quarterly; Sept 99, Vol. 43 Issue 3, p503, 16p.

De Vreese, Claes H. (2004) The Effects of Frames in Political Television News on Issue Interpretation and Frame Salience, Journalism \& Mass Communication Quarterly, Spring 2004, 81/1.

Forsberg, Tuomas \& Kekäle, Petri \& Ekholm, Peter (2001)Yleinen mielipide ja ulkopolitiikka. Hyvä renki muttei niin huono isäntäkään? [Public Opinion and Foreign Policy. A good servant but not such a bad master?] Ulkopolitiikka 3/2001, pp. 129-138.

Hofstede, Geert (2001) Culture's Consequences. Comparing Values, Behaviors, Institutions, and Organizations Accross Nations. Thousand Oaks CA: Sage Publications.

MTS (2006) Suomalaisten mielipiteitä ulko- ja turvallisuuspolitiikasta, maanpuolustuksesta ja turvallisuudesta [Finns' Opinions of Foreign and Security Policy, Defence, and Security]. Helsinki: The Advisory Board for Defence Information.

Mörä, Tuomo (1999) EU-journalismin anatomia. Mediasisältöjä muokanneet tekijät ennen kansanäänestystä 1994 [The Anatomy of EU Journalism. The Factors That Shaped Media Content Before the 1994 Referendum] Helsinki: University of Helsinki, Department of Communication, Series $1 \mathrm{~A} / 2$.

Rahkonen, Juho (2006) Journalismi taistelukenttänä. Suomen Nato-jäsenyydestä käyty julkinen keskustelu 2003-2004 [Journalism as Battlefield. The Public Discussion about Finland's NATO Membership 2003 to 2004]. Tampere: Tampere University Press.

Risse-Kappen, Thomas (1991) Public Opinion, Domestic Structure and Foreign Policy in Liberal Democracies. World Politics 43 (July 1991), pp. 479-512.

Snellman, Johan Vilhelm (1846/2005) Yleinen mielipide [Public Opinion] in J.V.Snellman. Collected works, part 6. Helsinki: Ministry of Education, pp. 92-97.

Splichal, Slavko (1999) Public Opinion. Developments and Controversies in the Twentieth Century. Lanham, MD: Rowman \& Littlefield.

Statistics Finland (2004) Suomen tilastollinen vuosikirja 2003 [The Statistical Yearbook of Finland 2003], Helsinki: Tilastokeskus.

Suhonen, Pertti (1997) The Media, Polls and Political Process. The Case of Finland. European Journal of Communication Vol. 12(2): pp. 219-238.

Torvi, Kai \& Pentti Kiljunen (2005) Onnellisuuden vaikea yhtälö. EVA:n kansallinen arvo ja asennetutkimus 2005. [The Difficult Equation of Happiness. EVA's National Survey on Values and Attitudes 2005]. Helsinki: Finnish Business and Policy Forum.

Visuri, Pekka (2006) Suomi kylmässä sodassa [Finland in the Cold War] Helsinki: Otava.

JUHO RAHKONEN, D.Soc.Sc., Researcher; Department of Journalism and Mass Communication, FI-33014 University of Tampere, juho.rahkonen@uta.fi 